The Effect of Cause Related Marketing on Consumer Purchase Intention

Toka Farouk Mohamed Ahmed Moussa

\title{
The Effect of Cause Related Marketing on Consumer Purchase Intention
}

\section{Toka Farouk Mohamed Ahmed Moussa}

\begin{abstract}
:
This study main purpose is to investigate the effect of Cause Related Marketing (CRM) campaigns on consumers purchase intention. A two (cause importance: sudden /disaster vs. ongoing) by two (cause proximity: national vs. international) between-subjects experimental design was utilized with 425undergraduate students participated in the study which carried out through online questionnaires. A One-Way ANCOVA was conducted by Using SPSS 22 which revealed that; First, CRM campaigns have a significant positive effect on consumers purchase intention. Second, consumers will have a positively significant higher purchase intention when CRM campaign is related to disaster rather than ongoing cause as well as there is a significant higher purchase intention when CRM campaign is related to national cause rather than international one.
\end{abstract}

Keywords: Cause Related Marketing (CRM), purchase intention, Cause importance, Cause proximity.

العدد الثالث الجزء الثاني 19

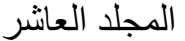


The Effect of Cause Related Marketing on Consumer Purchase Intention

Toka Farouk Mohamed Ahmed Moussa

\section{1- Introduction}

Cause Related Marketing involves mutual benefit of cooperative efforts between a business and a non-profit organization designed to promote the company's sales and the supported cause (Lee and Johnson, 2019). Cause Related Marketing is defined as a specific marketing activity in which the firm promises its consumers to donate company resources to a worthy social cause for each product or service sold. Cause Related Marketing strategy aims at two objectives: to support a social cause and to improve marketing performance (Varadarajan and Menon, 1988).While simultaneously increasing sales and consumer loyalty for the firm. In this respect, Cause Related Marketing could affect consumer's behavior; in a global study of Brandwatch: "The Complete Guide to Cause Marketing 2016", $91 \%$ of consumers said they were likely to switch to a brand that supports a good cause, given similar price and quality and $92 \%$ said that they would buy a product with a social or environmental benefit. Regarding to Nielsen's 2018 Report: "The Online Lives of Latin Consumers" noted that $57 \%$ of U.S. consumers agree that they are more likely to purchase brands that support a cause they care about and $43 \%$ agree they expect the brands they buy to support social causes. In a more recent study, Nielsen article "Global Consumers Seek Companies That Care about Environmental Issues 2018": $88 \%$ of respondents in Africa/Middle East say it is extremely or very important that 
The Effect of Cause Related Marketing on Consumer Purchase Intention

Toka Farouk Mohamed Ahmed Moussa

companies implement social programs to improve the environment.

Seeing that Cause related marketing campaigns become up-to-the-minute initiatives and continue to gain popularity, it is important to identify consumer attitudes and their purchasing intentions of products from companies engaging in Cause Related Marketing.

\section{2- Literature Review}

\section{1- The Concept of Cause Related Marketing}

CRM was regarded also by Pringle and Thomson (1999) and Demetriou et al. (2010) as a strategic marketing tool that involves the brand with considerable societal need for the common benefit by engaging consumers with specific cause and at the same time providing support for non-profit organizations.

There are three dimensions of Cause Related Marketing that related to the selection of causes themselves. First, Cause Importance; "Disaster or Ongoing Cause" related to the acuteness of the cause such as immediate caused that related to disaster relief or ongoing causes such as poverty (Du et al., 2008; Hou et al., 2008).

Second, Cause proximity; "Local/National or International "related to the location of the geographic area of the supported cause by CRM campaign (Cui et al. 2003). Previous research 
The Effect of Cause Related Marketing on Consumer Purchase Intention

Toka Farouk Mohamed Ahmed Moussa

have found that consumers are more likely to identify, support local/national causes rather than international causes (Hoeffler and Keller, 2002; Hou, Du and Li, 2008) because they perceive that as a something they get for their local community and a direct benefit for citizens.

Third, Cause type; "Primary or Secondary Needs" CRM campaign might support a cause linked to primary need (lifesaving/ life necessities) or a secondary need (life-enhancing) (Vanhamme, Lindgreen, Reast and Popering, 2012). CRM campaigns that engaging in supporting primary cause (e.g relieving poverty, breast cancer and hunger) are more likely to be preferred and produce higher level of identification rather than a secondary need that includes such as women rights, insuess related to community service and economic development (Berger et al. 1999 and Demetriou et al. 2010)

\section{2- Cause Related Marketing and Purchase Intention}

CRM could be a potential for differentiating a brand from its competitors and reflect favorability of consumers' market behavior. Bagozzi and Burnkrant (1979) state that an orientation that consumers may take for a product is called as purchase intention. Previous research generally indicates that, when consumers are asked to evaluate CRM campaigns, they express almost positive attitudes and purchase intentions toward

العدد الثالث الجزء الثاني 19 المجلد العاثر 
The Effect of Cause Related Marketing on Consumer Purchase Intention

Toka Farouk Mohamed Ahmed Moussa

companies tied up their products with specific cause (KoschateFischer, Stefan, \& Hoyer, 2012).

According to Edelman's 2018 Earned Brand Study; 64\% of consumers would choose, switch, avoid or boycott a brand based on its stand on societal issues. In addition to that, $86 \%$ of consumers believe that companies should take a stand for social issues and $64 \%$ of those who said it's 'extremely important' for a company to take a stand on a social issue said they were 'very likely' to purchase a product based on that commitment as was announced in 2018 Shelton Group's 'Brands \& Stands: Social Purpose is the New Black' study. Thus, there are some of recent researches that demonstrate the effect of CRM strategy on Consumer purchase intention.

The following studies examine the relationship between Cause Related Marketing and Consumers' behavioral responses in terms of attitude and purchase intention within different perspectives. Patel, Gadhavi and Shukla (2017) demonstrated the moderating role of cause involvement with a specific cause and skepticism in the relationship of Cause Related Marketing effect on attitudes and consumer purchase intention. In a more recent study Aggarwal and Singh (2019) investigated the impact of Cause Related Marketing campaigns on consumers purchase Intention in Indian context. They also evaluated how cause involvement could moderate the impact of Cause Related Marketing on purchase intention.

العدد الثالث الجزء الثاني 19

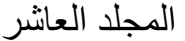


The Effect of Cause Related Marketing on Consumer Purchase Intention

Toka Farouk Mohamed Ahmed Moussa

One of the above-mentioned studies had used an experimental design which is Patel, Gadhavi and Shukla (2017) study. Aggarwal and Singh (2019) study was based on a selfadministered questionnaire. Although, the two studies used a different population type, sample size and statistical analysis technique for hypotheses testing, they almost reach to the same overall results. Below is a detailed description for each study.

Patel, Gadhavi and Shukla (2017) used a sample of 424 participants from two universities students. Participants were assigned randomly into two groups: experimental group and control group. Each experimental group participants were exposed to stimuli containing CRM offer which shows product portfolio, brand name and the advertisement. This CRM offer was eliminated from stimuli for the control group participants. One-way analysis (ANOVA) was performed to assess the differential effect of CRM offers on the variables and ANCOVA analysis was conducted to test the hypotheses.

Aggarwal and Singh (2019) Self-administered questionnaires were distributed among 1,425 consumers who used and familiar with CRM campaigns in five cities took part in this study then confirmatory factor analysis (CFA) was conducted using AMOS 23.0 in order to assess the reliability of measures and Hypotheses were tested by using structural equation modeling (SEM). Aggarwal and Singh (2019) study

العدد الثالث الجزء الثاني 19

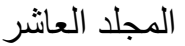


The Effect of Cause Related Marketing on Consumer Purchase Intention

Toka Farouk Mohamed Ahmed Moussa

revealed that Cause Related Marketing campaigns and cause involvement have a positive impact on the purchase intention towards products that associated with specific cause. Thus, the higher the level of customer's involvement with the cause, the higher purchase intention. In addition, Indians' level of involvement with a cause had a significant positive correlation with purchase intention.

These findings support results of Patel, Gadhavi and Shukla (2017) study which indicated that consumer has positive purchase intention and favorable attitude toward the brand engaging in CRM activities, in addition to favorable attitude toward the advertisement including CRM message. Study also revealed that consumers who are more involved with a cause have more favorable attitude towards the brand. And finally, skepticism has no effect on attitude towards the brand, attitude towards the advertisement and purchase intention and no significant effect was found between the interaction of cause Related Marketing offer and skepticism.

Whereas Patel, Gadhavi and Shukla (2017) and Aggarwal and Singh (2019) had used cause involvement as moderating variable in their research models; another research stream also examined the relationship between Cause Related Marketing and consumers' behavioral responses through focusing on the role of product category on purchase intention. Kureshi and Thomas

العدد الثالث الجزء الثاني 19

المجلد العاثر 
The Effect of Cause Related Marketing on Consumer Purchase Intention

Toka Farouk Mohamed Ahmed Moussa

(2018) designed their research model differently by testing the influence of donation message framing (exact/ calculable/abstract), donation magnitude and product category involvement (low involvement: shampoo vs. high involvement: laptop) on consumers purchase intention. The main aim of this study was to understand the effect of CRM communication on consumers purchase intention thoroughly. A sample included 180 participants of undergraduate students from a mid-sized university in India. An Experimental $(2 \times 3)$ between subject factorial designs were conducted through two separate experiments.

A two-way ANOVA analysis was performed to test the hypotheses of the two studies. Study 1 results indicated that there's significant support for the interaction between the donation message framing and the type of product category on purchase intention. In the way that, exact donation message framing in case of both high- involvement and low-involvement with products resulted in highest purchase intention for CRM related products. High-involvement products generates higher effect of donation message framing rather than low-involvement products except calculable donation message framing where no interaction effect of product involvement on purchase intention.

Study 2 showed that donation magnitude could affect on consumer purchase intention but it depends on the level of

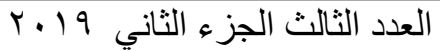

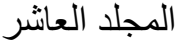


The Effect of Cause Related Marketing on Consumer Purchase Intention

Toka Farouk Mohamed Ahmed Moussa

consumer's involvement with the product. Positive attitude towards Cause Related Marketing campaigns didn't influence on the interaction of product category and donation magnitude on purchase intention. The results showed that; when the donation magnitude was low, consumers were more inclined to purchase the product regardless to the level of involvement they have of the product. The study recommended mentioning donation amount information while framing the CRM message as this would increase purchase intention for CRM products.

Although, the above mentioned studies; Patel, Gadhavi and Shukla (2017), Kureshi and Thomas (2018) and Aggarwal and Singh (2019) differs in investigating different factors and attributes in the relationship between cause Related Marketing and consumer purchase intention, They similarly found that Cause Related Marketing efforts significantly influenced purchase intention.

\section{3- Research Problem}

Over the past two decade, companies across the globe have increasingly adopted Cause Related Marketing that recognized as one of the fastest growing forms of marketing due to its capacity to power Company's social performance (Liu and Ko, 2011). Growth rate of Cause sponsorship by companies in their marketing campaigns increased from 700 million in 2000 to 2.06 billion in 2017 and predicted to reach $\$ 2.23$ billion in 2019, a

العدد الثالث الجزء الثاني 19

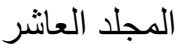


The Effect of Cause Related Marketing on Consumer Purchase Intention

Toka Farouk Mohamed Ahmed Moussa

projected increase of $4.6 \%$ over 2018(IEG Sponsorship Report,2018).However, only 24 companies in Egypt seem to be active in voluntary corporate initiatives( El-Bassiouny, Paul, and Mukhopadhyay, 2014).

To the best of our knowledge, our study incorporates a range of variables which experimentally examine Cause Related Marketing initiative that never investigated together before in Egyptian context.

The study problem could therefore be embodied in the following major questions:

RQ.1: What is the effect of Cause Related Marketing campaigns on consumer purchase intention in Egypt?

RQ.2: What is the effect of cause importance and cause proximity on consumer purchase intention within the Egyptian context?

\section{4- $\underline{\text { Research Objectives }}$}

Here are the objectives and purpose of the study.

First, this research seeks better understanding of consumers' response and willingness toward purchasing Cause Related Marketing products that support a worthy cause in Egypt.

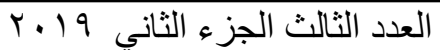

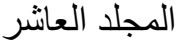


The Effect of Cause Related Marketing on Consumer Purchase Intention Toka Farouk Mohamed Ahmed Moussa

Second, we examine the effect of CRM campaigns on Egyptian consumers' responses in terms of their purchase intention.

Third, we inspect the role of cause importance and cause proximity as antecedents of CRM programs in improving purchase intentions of Egyptian consumers.

\section{5- Research Hypotheses}

Based on prior studies, the following main hypothesis is suggested:

H1: Cause Related Marketing Campaigns have a significantly positive impact on consumer purchase intention.

H1a: Consumers will most likely have higher purchase intention for companies supporting disaster rather than ongoing cause.

H1b: Consumers will most likely have higher purchase intention for companies supporting national cause rather than international cause.

العدد الثالث الجزء الثاني 9 1. المجلد العاشر 
The Effect of Cause Related Marketing on Consumer Purchase Intention

Toka Farouk Mohamed Ahmed Moussa

\section{6- Research Importance}

\section{1- Academic Importance}

Theoretically, the study will enrich the literature by empirically examining Cause Related Marketing campaigns on consumers' response in terms of their purchasing intention toward products involved in a worthy cause. Further; the research will examine the impact of cause importance (disaster or ongoing cause) and cause proximity (national or international) on Egyptian consumers' responses, so this research investigates the effect of Cause Related Marketing campaigns on Consumer Purchase Intention. Also, the researcher hopes to provide a better understanding of Cause Related Marketing and Consumers' purchase intention within Egyptian consumer market.

\section{2- Managerial importance}

Practically, the study will help companies' managers to understand how much Cause Related marketing is important as a strategic instrument that affect on brand image, product or overall company in customers' minds and build up strong relationship between the brand and consumers; it also fundamentally enhances sales for a specific product of a company associated with cause, maintaining brand positioning and produces revenues additionally. In a Parallel way, this study will help Managers to direct their effort to adapt Cause Related Marketing campaigns

العدد الثالث الجزء الثاني 19

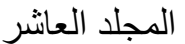


The Effect of Cause Related Marketing on Consumer Purchase Intention

Toka Farouk Mohamed Ahmed Moussa

associated with a worthy cause to enhance consumers' purchase intention of their products.

\section{7- $\underline{\text { Research Methodology }}$}

\section{1- Research Design}

To test our theoretical framework and hypotheses, we followed the instructions followed by(Grau and Folse, 2007; Anuar and Mohamad, 2011), we designed a 2 (cause importance: sudden /disaster versus ongoing) $\times 2$ (cause proximity: national versus international) between-subjects experimental design in which the study analyzed the effects of two attributes, treatments, or independent variables: cause importance (sudden /disaster vs. ongoing) and cause proximity (national vs. international) on the corporate image in minds of consumers and consequently on consumers' purchase intention (dependent variable).

\section{2- Experimental Stimuli}

We constructed four cells to represent combinations of two different cause composition types (cause importance and cause proximity) and communicated them in four different hypothetical scenarios to serve as stimuli for our experiment.

Hence, the hypothetical scenarios were created to manipulate the relevant variables in order to test their effect on corporate image and purchase intention. Each scenario given

العدد الثالث الجزء الثاني 19

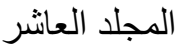


The Effect of Cause Related Marketing on Consumer Purchase Intention

Toka Farouk Mohamed Ahmed Moussa

included an informed consent and provided a brief description about a fictitious company (ABC Company) which produces coffee products (e.g. coffee drinks, hot and cold beverages, pastries and sandwiches).

\section{3- Participants}

Data were collected from a convenience sample of undergraduate students enrolled at Faculty of Commerce-English Section, Suez Canal University. The use of student samples is very common and convenient in the CRM research (Ellen Mohr and Webb, 2006; Lafferty, 2007; Lafferty and Goldsmith, 2004; Lii and Lee, 2012; Moosmayer and Fuljahn, 2010). In addition, homogeneous samples, such as students, facilitate the control of extraneous variables that could potentially confound the experiment results (Callow and Lerman, 2003; Kwok and Uncles, 2005)

\section{4- Data Collection and Procedure}

An experimental between-subjects research design was used with 425 participants from different classes completing an online survey in which respondents were randomly assigned to one of the four scenarios. Data was collected by using online questionnaire, the university has a database for English-Section students where the researcher sent most of them direct e-mails and invited them to take part in the survey. Moreover, the links

العدد الثالث الجزء الثاني 19

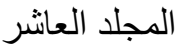


The Effect of Cause Related Marketing on Consumer Purchase Intention

Toka Farouk Mohamed Ahmed Moussa

of questionnaires had been posted online on the students' official groups for each academic year in which participants were randomly assigned to one of each questionnaire links.

\section{5-Measures}

The researcher would opretionalize the two independent treatments of CRM (cause importance and cause proximity) in four different scenarios/advertisement; Cause importance would be manipulated by one sentence with five point semantic differential scale in each scenario by asking participants to state that "a cause related to the problem in the scenario has occurred suddenly or [has been going on for some time]". At the same time, Cause proximity would be manipulated by one- sentence with five point semantic differential scale by asking respondents to state that "a cause related to the problem in the scenario has happened geographically close to you or [far away from you] adopted from Vanhamme, Lindgreen, Reast, and Popering (2012). On the other hand, Consumer Purchase Intention has been measured by using five-item, five point semantic differential scale (No Definitely Not/Yes Definitely) which adapted from Hou, Du and Li, (2008) and El-Bassiouny, Paul, and Mukhopadhyay (2014).

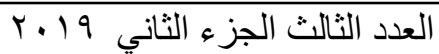

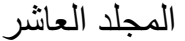


The Effect of Cause Related Marketing on Consumer Purchase Intention

\section{6- Data Analysis Strategy}

A One-Way ANCOVA would be employed by using SPSS (software version 22) to investigate the direct effect of Cause Related Marketing on Consumers purchase intention while controlling the confounding variable of cause involvement.

\section{8- Data Analysis and Results}

\section{1- Characteristics of the Respondents}

A convenience sample of 425 students completed the online questionnaire. Participants were at least 18 years of age from university students from different classes. They had enough English knowledge which enabled them to participate in the study. Among 425 students there were 251 females and 173 males.

\section{(Table 1) Descriptive Statistics of research variables}

\begin{tabular}{|c|c|c|c|c|c|}
\hline constructs & N & Minimum & Maximum & Mean & Std. Deviation \\
\hline Total.Img & 425 & 1.80 & 5.00 & 3.5158 & .79394 \\
\hline Total.PI & 425 & 1.20 & 5.00 & 3.3360 & .79387 \\
\hline Total.Inv & 425 & 1.00 & 5.00 & 3.1067 & 1.18875 \\
\hline Scenrios & 425 & 1 & 4 & 2.43 & 1.139 \\
\hline
\end{tabular}

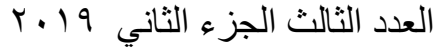


The Effect of Cause Related Marketing on Consumer Purchase Intention

Toka Farouk Mohamed Ahmed Moussa

\section{2- Measurement Model}

Data was cleaned, coded and prepared on SPSS before running any statistical analysis. Standard deviation (SD) was conducted and there were two subjects excluded from 427 participants completed the survey. As we rejected subjects of SD $<0.5$ in which valid sample size was 425 of respondents.

Before testing our hypotheses, we confirmed that the data has met the regression assumptions. The data was checked that it was normally distributed. Also assuring that there were no significant outliers and the homogeneity of variance was conducted where none of assumptions was violated.

Factor Reduction test was conducted in order to ensure that items of research's variables fit onto a single theoretical construct. Research constructs were examined and the test revealed that they are extracted on only one factor, which means that CI, PI and Involvement have been considered as one dimension/scale. Items with cross loading (>.25) and low factor loadings $(<.40)$ were eliminated. To assess scale reliability, the internal consistency of the items on each factor was measured using Cronbach's Alpha. The closer the Cronbach's alpha is to 1, the higher is the internal consistency reliability (Sekaran, 2003). Thus, overall the measures achieved internal consistency according to acceptable cutoff values indicated in the literature.

العدد الثالث الجزء الثاني 19

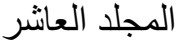


The Effect of Cause Related Marketing on Consumer Purchase Intention

\section{3- Results}

One-way cross-sectional ANCOVA revealed that there is a significant positive effect of four scenarios (CRM campaigns) on consumers purchase intention after controlling for the effect of cause involvement [F (test value) $=29.952, \mathrm{P}=0.000]$ which supported the main first hypothesis.

(Table 2): Tests of Between-Subjects Effects

\begin{tabular}{|c|c|c|c|c|c|c|}
\hline Source & $\begin{array}{c}\text { Sum of } \\
\text { Squares }\end{array}$ & df & $\begin{array}{c}\text { Mean } \\
\text { Square }\end{array}$ & F & Sig. & $\begin{array}{c}\text { Partial Eta } \\
\text { Squared }\end{array}$ \\
\hline $\begin{array}{c}\text { Corrected } \\
\text { Model }\end{array}$ & 145.328 & 4 & 36.332 & 125.188 & .000 & .544 \\
\hline Intercept & 116.937 & 1 & 116.937 & 402.927 & .000 & .490 \\
\hline Total.Inv. & 10.225 & 1 & 10.225 & 35.233 & .000 & .077 \\
\hline Scenrios & 26.078 & 3 & $\mathbf{8 . 6 9 3}$ & 29.952 & .000 & .176 \\
\hline Error & 121.892 & 420 & .290 & - & - & - \\
\hline Total & 4997.000 & 425 & - & - & - & - \\
\hline $\begin{array}{c}\text { Corrected } \\
\text { Total }\end{array}$ & 267.219 & 424 & - & - & - & - \\
\hline
\end{tabular}

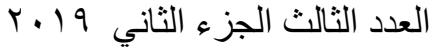

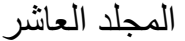


The Effect of Cause Related Marketing on Consumer Purchase Intention

Toka Farouk Mohamed Ahmed Moussa

In Order to test $\mathrm{H} 1 \mathrm{a}$ and $\mathrm{H} 1 \mathrm{~b}$, Comparison of the estimated marginal means was conducted. (Table 3) indicates that CRM campaigns that related to disaster/sudden cause had a higher positive significant effect on consumers' intention to purchase products linked to CRM offer rather than CRM campaigns that supported an ongoing cause as $\mathrm{M}_{\text {scenr1 }}=3.823>\mathrm{M}_{\text {scenr3 }}=3.226$. Thus, H1a is confirmed. On the other hand, regarding to H1b; CRM initiatives that linked to a national cause which took place in close geographic area had a higher significant positive effect on consumers purchase intention rather than CRM campaigns related to international cause that occurred far away from consumers $\mathrm{M}_{\text {scenr3 }}=3.226>\mathrm{M}_{\text {scer4 }}=2.883$. These results point out that $\mathrm{H} 2 \mathrm{~b}$ is accepted.

\section{(Table 3) Estimated Marginal Means of the Dependent Variable: Purchase intention}

\begin{tabular}{|c|c|c|c|c|}
\hline \multirow[b]{2}{*}{ Scenarios } & \multirow[b]{2}{*}{ Mean } & \multirow[b]{2}{*}{ Std. Error } & \multicolumn{2}{|c|}{ 95\% Confidence Interval } \\
\hline & & & Lower Bound & Upper Bound \\
\hline 1 & $3.823^{a}$ & .066 & 3.693 & 3.954 \\
\hline 2 & $3.320^{\mathrm{a}}$ & .059 & 3.204 & 3.436 \\
\hline 3 & $3.226^{\mathrm{a}}$ & .060 & 3.107 & 3.345 \\
\hline 4 & $2.883^{\mathrm{a}}$ & .078 & 2.730 & 3.035 \\
\hline
\end{tabular}

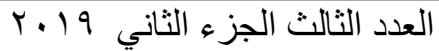

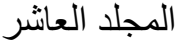


The Effect of Cause Related Marketing on Consumer Purchase Intention

Toka Farouk Mohamed Ahmed Moussa

\section{9- Empirical and Managerial Implications}

The main empirical implication of this study is that Consumer behavioral responses in favor of the brand (purchase intention) and supporting a specific worthy cause are reinforced in the context of employing a disaster and national cause. On the other hand, the results of our study have meaningful implications for marketers who want to employ CRM as a marketing strategy.

The current study confirmed that cause importance and cause proximity are important factors that influence consumers' purchase intentions in the Egyptian context. Compassionate consumers will perhaps be willing to purchase the product even the CRM campaign support an ongoing cause or international cause, but this lessens in comparison to campaigns employ a disaster or national cause which returns with benefit to the Egyptian society. The company must select an appropriate organization from the target audience point of view (Boush, Friestad and Rose, 1994). The selection of a suitable cause could also help the company in boosting its credibility and generating positive word of mouth from the consumer.

\section{0- $\quad$ Limitations and Prospects for Future Research}

While this study has implications for emerging markets, some limitations need to be acknowledged.

العدد الثالث الجزء الثاني 19

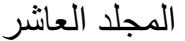


The Effect of Cause Related Marketing on Consumer Purchase Intention

Toka Farouk Mohamed Ahmed Moussa

First, the study scope is limited to Egypt; further research could be carried out in other countries to increase the generalizability of finding. Also further research should conduct comparative studies with consumers from different cultures and different buying behaviors specifically in Arab countries which would result a contribution for literature

Second, another limitation was the narrow focus of the study. We restricted the focus only on two elements of CRM communication. Future research should include a wider range of determinants with large samples sizes for each element. Therefore, several other factors and elements related to CRM could affect purchase intention (e.g., message appeal, brand familiarity, cause fit, message framing, skepticism and donation type) were not examined and it's recommended for future studies to examine such attributes in their proposed model.

Third, another limitation of the study was that during the experiment each respondent was exposed to only one combination of the independent variables (four scenarios). Future investigation could try to provide them several or pairs of combinations and empirically test for differences.

\section{1- Discussion and Conclusion}

Given the fact that corporations are operating under increasing competition, they need to differentiate their brand in

العدد الثالث الجزء الثاني 19

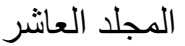


The Effect of Cause Related Marketing on Consumer Purchase Intention

Toka Farouk Mohamed Ahmed Moussa

the marketplace and enhance their corporate image and generate incremental sales. Into the bargain, they need to engage in socially responsible behaviors because of today's growing necessity that the society need to support good causes.

Accordingly, CRM becomes universal practice for firms to engage their products with specific cause linked to non-profit organizations and charities as it has been seen as a way for companies to achieve both corporate and non-profit objectives (Samu \& Wymer, 2009). The current study contributes to the literature by validating some of the previous findings based on using scenarios and experimental design in Egypt focusing on two main causes (cause proximity; national vs. international cause and cause importance; disaster vs. ongoing cause) at the same time.

Finally, when conducting and implementing a CRM campaigns, businesses should keep their minds on to the choice of the cause, as this may be an prominent determinant of influencing the intention to purchase company products associated with the cause (Duarte, Silva, 2018), they also should pay attention for targeting the right public which is also critical to the success and effectiveness of CRM offer.

\section{$\underline{\text { References }}$}

1. Aggarwal, V., \& Singh, V. K. (2019). Cause-related marketing and startups: moderating role of cause involvement. Journal of Global Responsibility, 10(1), 16-30.

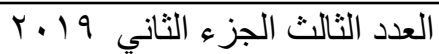
المجلد العاثر 
The Effect of Cause Related Marketing on Consumer Purchase Intention

Toka Farouk Mohamed Ahmed Moussa

2. Anuar, M. M., \& Mohamad, O. (2011). Examining the effects of causeproximity and gender on consumers' response to cause-related marketing: evidence from Malaysia. International Journal of Marketing Studies, 3(3), 174.

3. Armas and McCaskill, (2018, Sep 3). The Online Lives of Latin Consumers. Retrieved from https://www.nielsen.com/eg/en/

4. Bagozzi, R. P., \& Burnkrant, R. E. (1979). Attitude organization and the attitude-behavior relationship. Journal of personality and social psychology, 37(6), 913.

5. Berger, I. E., Cunningham, P. H., \& Kozinets, R. V. (1999). Consumer persuasion through cause-related advertising. Advances in Consumer Research, 26, 491-497.

6. Boush, D. M., Friestad, M., \& Rose, G. M. (1994). Adolescent skepticism toward TV advertising and knowledge of advertiser tactics. Journal of consumer research, 21(1), 165-175.

7. Callow, M. A., \& Lerman, D. B. (2003). Consumer evaluations of price discounts in foreign currencies. Journal of Product \& Brand Management, 12(5), 307-321.

8. Cui, Y., Trent, E. S., Sullivan, P. M., \& Matiru, G. N. (2003). Causerelated marketing: How generation Y responds. International Journal of Retail \& Distribution Management, 31(6), 310-320.

9. Demetriou, M., Papasolomou, I., \& Vrontis, D. (2010). Cause-related marketing: Building the corporate image while supporting worthwhile causes. Journal of Brand Management, 17(4), 266-278.

10. Demetriou, M., Papasolomou, I., \& Vrontis, D. (2010). Cause-related marketing: Building the corporate image while supporting worthwhile causes. Journal of Brand Management, 17(4), 266-278.

11. Du, L., Hou, J. and Huang, Y. (2008), "Mechanisms of power and action for cause-related marketing: perspectives of enterprise and non-profit organizations", Baltic Journal ofManagement, Vol. 3 No. 1, pp. 92-104.

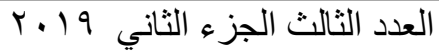

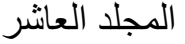


The Effect of Cause Related Marketing on Consumer Purchase Intention

Toka Farouk Mohamed Ahmed Moussa

12. Ellen, S.P., Mohr, A.L. and Webb, J.D. (2000), “Charitable programs and the retailer: do they mix",Journal of Retailing, Vol. 76 No. 3, pp. 393-406.

13. Grau, S. L., \& Folse, J. A. (2007). The influence of donation proximity and message-framing cues on the less-involved consumer. Journal of Advertising, 36(4), 19-33.

14. Hammad, H., El-Bassiouny, N., Paul, P., \& Mukhopadhyay, K. (2014). Antecedents and consequences of consumers' attitudinal dispositions toward cause-related marketing in Egypt. Journal of Islamic Marketing, 5(3), 414-445.

15. Hoeffler, S. and Keller, K. (2002), "Building brand equity through corporate societal marketing",Journal of Public Policy \& Marketing, Vol. 21 No. 1, pp. 78-89.

16. Hou, J., Du, L. and Li, J. (2008), "Cause's attributes influencing consumer's purchasing intention: empirical evidence from China", Asia Pacific Journal of Marketing and Logistics, Vol. 20No. 4, pp. 363-380.

17. Koschate-Fischer, N., Stefan, I. V., \& Hoyer, W. D. (2012). Willingness to pay for cause-related marketing: The impact of donation amount and moderating effects. Journal of marketing research, 49(6), 910-927.

18. Kureshi, S., \& Thomas, S. (2018). Testing the influence of message framing, donation magnitude, and product category in a cause-related marketing context. Journal of Marketing Communications, 1-22.

19. Kwok, S., \& Uncles, M. (2005). Sales promotion effectiveness: the impact of consumer differences at an ethnic-group level. Journal of Product \& Brand Management, 14(3), 170-186.

20. Lafferty, B. A. (2007). The relevance of fit in a cause-brand alliance when consumers evaluate corporate credibility. Journal of Business Research, 60(5), 447-453.

21. Lafferty, B. A., Goldsmith, R. E., \& Hult, G. T. M. (2004). The impact of the alliance on the partners: A look at cause-brand alliances. Psychology \& Marketing, 21(7), 509-531.

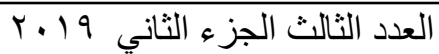

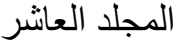


The Effect of Cause Related Marketing on Consumer Purchase Intention

Toka Farouk Mohamed Ahmed Moussa

22. Lee, J. Y., \& Johnson, K. K. (2019). Cause-related marketing strategy types: assessing their relative effectiveness. Journal of Fashion Marketing and Management: An International Journal.

23. Lii, Y. S., \& Lee, M. (2012). Doing right leads to doing well: When the type of CSR and reputation interact to affect consumer evaluations of the firm. Journal of business ethics, 105(1), 69-81.

24. Liu, G.,\&Ko,W-W.(2011).Ananalysisofcauserelatedmarketingimplementation strategies through social alliance: Partnership conditions and strateg icobjectives. Journal of Business Ethics, 100(2), 253-281.

25. Patel, J. D., Gadhavi, D. D., \& Shukla, Y. S. (2017). Consumers' responses to cause related marketing: moderating influence of cause involvement and skepticism on attitude and purchase intention. International Review on Public and Nonprofit Marketing, 14(1), 1-18.

26. Pringle, H., \& Thompson, M. (1999). Brand spirit: How Cause Related Marketing Builds Brands. John Chichester: Willey \& Sons. Radziszewska, A. (2013). Crowdsourcing as a form of utilizing virtual communities innovation, Contemporary Management Quarterly 2, 180- 189.

27. Samu, S., \& Wymer, W. (2009). The effect of fit and dominance in cause marketing communications. Journal of Business Research, 62(4), 432-440.

28. Smith, k. (2016, Nov 23). The Complete Guide to Cause Marketing. Retrieved from https://www.brandwatch.com/blog/cause-marketing/

29. Vanhamme, J., Lindgreen, A., Reast, J., \& Van Popering, N. (2012). To do well by doing good: Improving corporate image through cause-related marketing. Journal of business ethics, 109(3), 259-274.

30. Varadarajan, P.R. and Menon, A. (1988), "Cause-related marketing, a coalignment of marketing strategy and corporate philanthropy", Journal of Marketing, Vol. 52No. 3, pp. 58-74.

العدد الثالث الجزء الثاني 19

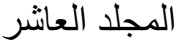

